
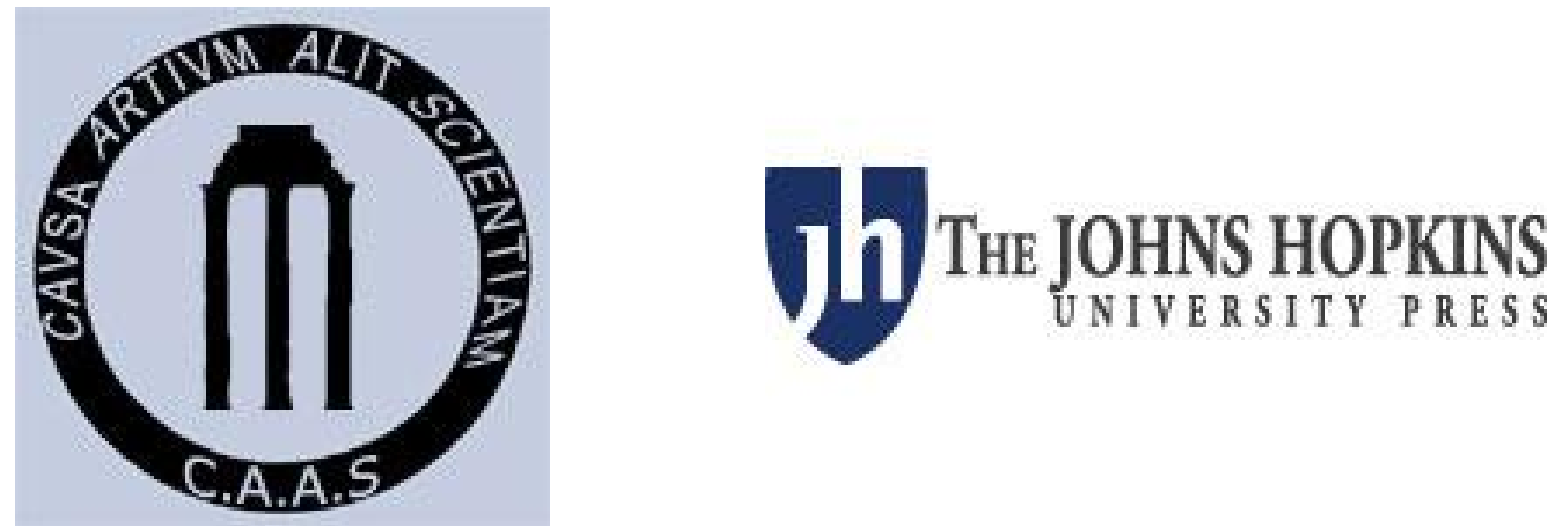

Nausicaa: A Feminine Threat

Author(s): Nicolas P. Gross and Nicholas P. Gross

Source: The Classical World, Vol. 69, No. 5 (Feb., 1976), pp. 311-317

Published by: The Johns Hopkins University Press on behalf of the Classical Association of the Atlantic States

Stable URL: http://www.jstor.org/stable/4348437

Accessed: 08-08-2016 18:29 UTC

Your use of the JSTOR archive indicates your acceptance of the Terms \& Conditions of Use, available at

http://about.jstor.org/terms

JSTOR is a not-for-profit service that helps scholars, researchers, and students discover, use, and build upon a wide range of content in a trusted digital archive. We use information technology and tools to increase productivity and facilitate new forms of scholarship. For more information about JSTOR, please contact support@jstor.org.

Classical Association of the Atlantic States, The Johns Hopkins University Press are collaborating with JSTOR to digitize, preserve and extend access to The Classical World 


\section{Nausicaa: A Feminine Threat}

From ancient times to the present Homer's treatment of Nausicaa has elicited scholarly criticism. The scholiasts (probably Aristarchus alone), despite conclusive evidence of authenticity, doubted every explicit suggestion of marriage between Odysseus and the Phaeacian princess. ${ }^{1}$ Even when modern scholars are more sympathetic to the romantic potential of the young woman's story, they are no less critical of Homer. Woodhouse has distinct misgivings about the farewell scene between Nausicaa and Odysseus: "Who does not feel that there is something hard and unsatisfying in this ending of her first passion?"' Stanford also seems to consider the poet's leave-taking of the princess problematical: "Yet there is a certain ruthlessness in Homer's treatment of Nausicaa." ${ }^{3}$ The most recent and harshest indictment of Homer is that of G. Vallillee. Presuming that the demands of folk-tale romance (a happy ending, i.e., marriage between Nausicaa and Odysseus) and those of the epic narrative (the wanderer's return to Penelope) are incompatible, he brands this farewell a "tragic artistic blunder," an episode for which "it is hard . . . to forgive Homer." "Since Odysseus' eventual return to Penelope is undeniable, what assumptions about Nausicaa's role have produced such a reaction? Has Homer extensively used a folk-tale source in the Phaeacian episode only to fail to integrate it with the epic narrative of the Odyssey? In view of the continued disappointment with this Homeric scene, these questions demand further consideration, and I hope to show that the poet, far from needing forgiveness, has created an episode coherent in action and character.

Not only does discontent with the final encounter between Odysseus and Nausicaa urge a re-evaluation of the Phaeacian princess's role, but so too does G. P. Rose's new perspective on the hero's stay in Scheria. In his "The Unfriendly Phaeacians"s Rose convincingly argues that the Phaeacian court provides not an environment of luxurious leisure but rather a social testing ground for Odysseus; Rose does not, however, consider Nausicaa's function within this inimical setting. Although the princess attends neither court nor games nor Odysseus' eventual departure, she too represents a problem and one more personal and delicate than that of the royal court. Her communication with the wanderer tends to be private, and at their final meeting

\footnotetext{
'On the authenticity of the text here see R. Lattimore, "Nausikaa's Suitors," Illinois Studies in Language and Literature 58 (1969) 88-102. An earlier version of this paper was presented to the one-hundred-and-fifth annual meeting of The American Philological Association in St. Louis, December, 1973.

${ }^{2}$ The Composition of Homer's Odyssey (Oxford 1929) 64.

${ }^{3}$ The Odyssey, 2nd ed. (New York 1961) note on 8.457ff. (hereafter Stanford, The Odyssey).

4 “"The Nausicaa Episode," Phoenix 9 (1955) 179.

${ }^{5} T A P A 100$ (1969) 387-406.
} 
they are quite alone, an isolation which can only intensify the anticipation of romance. Yet the challenges of Nausicaa and court are not completely separate. Amatory involvement would only arouse hostility - witness the Euryalus episode - as well as endanger Odysseus' reunion with Penelope were he still to return home. ${ }^{6}$ Slight offense could increase Phaeacian distrust. Odysseus tells one lie in Scheria, a falsehood in defense of Nausicaa's reputation (7.303-307), and the doting Alcinous is so overwhelmed with gratitude that he offers Odysseus his house, his wealth and even his daughter. Thus, the Ithacan must tread a narrow path between Phaeacian suspicion and Nausicaa's attraction to him, since the princess has considerable ability to affect both his prospects in Scheria and his eventual renewal of marriage.

The circumstances of Odysseus' initial confrontation with Nausicaa are charged with amatory potential and, as Stanford has shown, ${ }^{7}$ present a challenge even to the eloquence of this skillful speaker. Not only is Odysseus naked, but the princess is present on the beach because Athene, having left her acutely aware of her sexual potential (6.33), has instructed her to wash clothing for an imminent marriage to a provocatively unidentified groom. Far from being overcome by the situation, however, the wily speaker makes use of these implicit possibilities in a speech of studied ambiguity. In fact, his first word gounoumai reflects the approach of his entire address, for Odysseus thus puts himself in the posture of a suppliant in order to calm the well-justified anxieties of the young woman. Yet he does not embrace her knees and later apologizes for the oversight, though it was intentional (6.16869). Typical, likewise, of the suggestive yet appropriate nature of his words are the flattering comparisons of Nausicaa to Artemis (151) and to a young palm shoot on Delos (161-63); both imply slimness and grace without an overt, sensual element.

It should be noted, however, that the pervasive impression of guarded intimation results not only from a single line or section but especially from the subtle verbal juxtapositions within a given part of Odysseus' speech. For example, immediately after speculating on the good fortune of her eventual husband (158-59), he states his own reaction to the young woman's appearance:

$$
\text { ou gar pô toiouton egô idon opthalmoisin (160). }
$$

Yet the statement remains appropriate since Odysseus declares that, as he gazes, he is held by awe, sebas (161), and thereby recalls the divine quality of Nausicaa's beauty. This expression of admiration is not overly strong, but, given the location, it creates an impression of interest and attraction more forceful than the line's denotative meaning. In fact, the Ithacan consistently

\footnotetext{
${ }^{6}$ W. B. Stanford, The Ulysses Theme, 2nd ed. (Oxford 1964) 54.
}

\footnotetext{
${ }^{7}$ Stanford's perspective on this speech (above, note 6) $52-54$ aided me in developing my own view; I find, however, the address more ambiguous than Stanford suggests. Cf. H. W. Clarke, The Art of the Odyssey (Englewood Cliffs, N.J. 1967) 52-53 and C. Fantazzi, "Courtly Odysseus," International Homeric Symposium, The Communications (Athens 1970) 33-34.
} 
employs this strategy. Just as he suggests the princess's beauty at the beginning and end of the prooemium, so too in conclusion he recalls the earlier reference to marriage (158-59):

\section{Prooemium: 149 gounoumai ... gounôn hapsasthai \\ 149-152: Nausicaa's possible divinity \\ 153-159: Nausicaa's possible mortality (her family's and future husband's reaction) \\ 160-169: the divine quality of Nausicaa's beauty (Odysseus' re- action) \\ Narration: 169 chalepon ... 177: summary of sea voyage from Ogygia to Scheria and appeal to pity \\ Request: 178-179 "show me a city, give me a rag" \\ Conclusion: $180-185$ prayer for a happy marriage for Nausicaa}

The tight organization reveals a degree of restraint, for Odysseus' purpose is ostensibly to gain Nausicaa's goodwill and to quiet her anxieties, but in view of the flattery and strategically placed references to marriage, there is little wonder that Nausicaa, informed by Athene of immanent nuptials (6.27) should assume Odysseus the right man. Although he succeeds in alleviating his immediate wants, the wanderer has helped to provoke yet another predicament.

After he has washed the salt-brine from himself and has been showered with divine radiance by Athene (6.235), Nausicaa declares to her handmaids that she would like to marry such a man (244-45). Indeed, when she speaks to Odysseus to advise him of the best course of action in Scheria, her interest is scarcely concealed. Because of her sense of propriety, however, a fictional Phaeacian sailor mentions the possibility of marriage, for she has cleverly set his speech within her own as an example of the gossip which she wishes to avoid, the reason for their not entering the city together (6.273-88). Although critics, notably Stanford and Woodhouse, regularly assign the adjective "naive" to Nausicaa and her speech, ${ }^{8}$ such a label hardly seems appropriate. Both the form and content of the address argue against such a view. Indeed, the young princess's awareness of the implications of gossip suggests an adult sensitivity to social mores as does her own condemnation of young women who by indulging in sexual relations, misgêtai (288) do not heed their parents. The deliberate speech within a speech cannot be considered an artless or unconscious device. The same applies, more significantly, to the princess's inclusion of several of the very topics which Odysseus had used in his address.

Through the medium of the ficitonal Phaeacian, Nausicaa calls Odysseus kalos te megas; she flatters his physical attractiveness. ${ }^{9}$ And this introduc-

${ }^{8}$ Stanford (above, note 6) 53 and Woodhouse (above, note 2) 58.

${ }^{9}$ See H. Ebeling (ed.), Lexicon Homericum (Leipzig 1885) vol. 1, 641. 
tion, like Odysseus' first words to her, is expressed by rhetorical questions (276-77). Furthermore, Nausicaa suggests that Odysseus may be an immortal: $\hat{e}$ tis hoi euksamenêi poluarêtos theos êlthen (280). Note here that euksamenêi and poluarêtos emphasize Nausicaa's longing for an extraordinary man, and this desire is clearly connected with marriage since she has already (through the Phaeacian sailor) referred to Odysseus as her future husband (277). Immediately after suggesting Odysseus' divinity, the verbal puppet says that Nausicaa will have him all her days (281) and again calls him husband, posin (282). To conclude, the garrulous sailor says that Nausicaa cares nothing for the nobles (esthloi, 284) who court her - a strong statement which implies not only her desirability and high social rank, but also her availability. ${ }^{10}$ These expressions of amatory interest, however, go beyond mere flattery, for, as comparison indicates, they have their origin in Odysseus' speech:

1) Both praise the other's physical attractiveness.

a) Odysseus compares Nausicaa to Artemis.

b) Nausicaa (through the imaginary Phaeacian) calls Odysseus kalos te megas.

2) Both clearly stress the other's possible divinity.

a) Odysseus asks if Nausicaa is theos.

b) Nausicaa calls Odysseus theos.

3) Both imply the excellence of their characters and social ranks.

a) Odysseus came to Delos as the leader of a great host.

b) Nausicaa is pursued by noble suitors.

4) Both imply great personal interest in the other.

a) The longest distinguishable section of Odysseus' speech is an adroitly expressed description of his reaction to Nausicaa's beauty, and, as a whole, his speech contains implications of marriage.

b) Nausicaa refers to Odysseus specifically as her probable husband (posis) twice $(277,282)$.

Although Nausicaa expresses herself with a modest indirectness, her intentions, nonetheless, are specific and explicit. From her not unskillful imitation of his address, the eloquent speaker must realize that he not only confronts a young woman of considerable talent and charm but that his own words have encouraged her response.

After this encounter, Nausicaa and Odysseus will not communicate again until their second and final meeting (8.454-68). Despite her absence, the expectation for a liaison developed through the two speeches continues to involve the adventurer in difficulties. His lie (7.303-307) to Alcinous saves Nausicaa's reputation and his own; nonetheless, the king's suggestion that Odysseus become his son-in-law (7.313) brings further trouble. Euryalus, a

\footnotetext{
${ }^{10}$ For the interpretation of individual lines of Nausicaa's speech I am indebted to Woodhouse (above, note 2) 58 and Stanford. The Odyssey (above, note 3) notes on 6.276-288. Neither of these scholars, however, compares Nausicaa's address to that of Odysseus.
} 
suitor to the princess, is evidently stung by this sudden offer to a foreigner" and later rudely taunts the Ithacan (8.159-64) for his failure to compete in athletic games. By his consequent participation in a contest similar to courtship-rivalry, Odysseus nearly destroys the developing rapport between himself and his hosts. To rebuke the young man, Odysseus charges that he is illspoken (166). Here the Ithacan emphasizes the superiority of an eloquent individual to a handsome fool such as Euryalus (177), for the well-spoken man, according to Odysseus, compensates for lack of comeliness with the grace of his words even to the extent that he seems godlike (169-73). Such an image may well recall the Ithacan's skillful address to the young princess; surely it describes Odysseus himself (cf. Il. 3.216-24). Immediately thereafter, he boasts of his considerable ability with the bow (202-33). ${ }^{12}$ In harshly offering this challenge to the Phaeacians, the hero momentarily takes on the typical, overbearing quality of suitors in the Odyssey. In short, Odysseus is caught up by the momentum of the situation and participates in the rivalry for the hand of Nausicaa.

To ease the tension of the Euryalus-Odysseus confrontation, Demodocus sings the famous and frivolous song of Ares and Aphrodite. ${ }^{13}$ While Odysseus' reaction to the tale is a significant factor in renewing the rapprochment between him and his hosts, nonetheless, his obvious delight in this erotic fable further underscores the anticipation of a liaison and consequently threatens his homeward journey. Although Demodocus' narrative has been described as a marriage song, its subject is adultery and emphasis sensual pleasure. Ares and Aphrodite are caught in flagrante and observed by the Olympian gods (8.321-27); however, Hermes when asked if he would like to lie with Aphrodite (8.335-37), replies that he would, despite the embarrassment of a divine audience (8.341). The punishment of being made ridiculous becomes meaningless. Moreover, the injured party, Hephaestus, is persuaded by Poseidon to free Ares, and whether he will receive any compensation is, at least, open to question. ${ }^{14}$ Aphrodite is hardly less guilty than Ares, but no suggestion of punishment appears even though she receives con-

\footnotetext{
"Since prominent Phaeacians were in court (7.98) when Alcinous made the offer of marriage, Euryalus could have been in attendance then. It seems highly unlikely that such a startling statement could have failed to arouse comment especially among a people noteworthy for their love of gossip. See J. van Leeuwen (ed.), Homeri Carmina, Odyssea (Leyden 1917) notes on 8.100-233 and 8.159-64. Cf. Lattimore (above, note 1) 99 and Woodhouse (above, note 2) 61.

${ }^{12}$ If we accept Stanford's view (above, note 6) 71 that Odysseus' speeches are customarily characterized by their functionality, then his boast here is most unusual since it causes considerable strain in his relations with the Phaeacians; Rose (above, note 5) 403.

${ }^{13}$ The Analysts have doubted the authenticity of the Ares-Aphrodite song, but its genuineness has been asserted by W. Burkert, "Das Lied von Ares und Aphrodite," RhM 103 (1960) 13044. Cf. F. R. Bliss, "Homer and the Critics: The Structural Unity of Odyssey Eight," Bucknell Review 16, 3(1968) 53-73 and W. F. J. Knight, Many-Minded Homer (London 1968) 152-53.
}

${ }^{14}$ Stanford, The Odyssey (above, note 3) note on 8.351-53. 
siderable attention at the end of the song (362-66). Clearly the bard has emphasized sensual indulgence rather than moral rectitude. Odysseus' approval of this song helps to unite him with the Phaeacians; ${ }^{15}$ their responses are identical and described by a single verb (terpet', 368).

When Odysseus and Nausicaa meet for the second and last time, amatory expectation reaches its height. As if to provoke an affair, situational recollections of their earlier meeting precede the encounter. Before their first introduction, Odysseus was awakened by the shrieks of Nausicaa's handmaids whose ball had strayed during a game, a game referred to as a dance (molpês, 6.101). Shortly thereafter Odysseus praises Nausicaa's skill at dancing (6.15457). In Book Eight, just after the Ares-Aphrodite song, Nausicaa's brothers perform a dance which involves throwing a ball (372-80). There is yet another parallel. Nausicaa first makes explicit her interest in Odysseus after he has taken a bath, and before their parting words she marvels at his appearance as he is coming from another bath. After the wanderer's first bath, Nausicaa's admiration is expressed by a single word, thêeito (6.237); she then says she would like to marry him. When she sees him after the second bath, she is alone and apparently awaiting him - she has surmised (if not requested) the information of his whereabouts. It is worth noting that a whole line describes her response: thaumadzen d' Odusêa en ophthalmoisin horôsa (8.459).

Thus, when Nausicaa asks that Odysseus remember her ${ }^{16}$ because he owes her his life (461-62), the situation is fraught with difficulty for the hero, amatory temptation from without and quite probably from within. The many parallels between the first and last encounter are joined by a strong reminder of Odysseus' responsiveness to women, for this is the only passage or book in which the names of Circe (448) and Calypso (452), Odysseus' divine paramours, and Nausicaa are mentioned in close proximity. Significantly the princess is described here as a divine beauty: theôn apo kallos echousa (457). So too the wanderer's reaction to Euryalus' challenge linked him with her suitors, and his delight in the Ares-Aphrodite song suggests a receptiveness to pleasure. Yet before he reaches Ithaca and reunion with Penelope, he must not merely escape temptation, but he must gracefully and tactfully close his relationship with Nausicaa. Arete, the real power on Scheria, has yet to be fully won over, and he will remain on the island a third day. To the young woman, therefore, Odysseus replies that he will pray to her as a goddess always because she saved him (467-68). In sense, if not in phrase, Odysseus' speech imitates that of Nausicaa. Once again to extricate himself from a difficult situation, he recalls the flattery of his first address by suggesting that

\footnotetext{
${ }^{15}$ Rose (above, note 5) 403.

${ }^{16}$ Apollonius Rhodius apparently read this line as an amatory overture, for Medea closely imitates it when she initiates her affair with Jason, Argonautica 3.1069 and 1110. See M. M. Gillies, The Argonautica of Apollonius Rhodius Book III (Cambridge 1928) 110. Cf. A. Ardizzoni, Le Argonautiche, Libro III (Bari 1958) 220 and F. Vian, Apollonios de Rhodes, Argonautiques, Chant III (Paris 1961) 133.
} 
the young woman is goddess-like. But this time his words cannot be interpreted as an amatory gesture. In short, his final speech is as polite, deferential, and genuinely extravagant in praise as was his earlier address, but unequivocal.

Nor does Odysseus reveal any insensitivity to Nausicaa. To the contrary his reply and immediate departure express restraint and wisdom. Despite temptation, Odysseus, now more provident for his two days on Scheria, must realize that consummation could only damage both. Throughout the episode, the princess has been portrayed as an intelligent and charming young woman (witness scholars' sympathetic response to her) but at the same time her attraction to Odysseus poses an ever-present problem for him. ${ }^{17}$ Thus, the folktale source, far from being misused, deliberately heightens the expectation for liaison so that Homer may all the more emphatically present the mature and humane response of his hero to a very human temptation. If the audience has been lulled into the anticipation of romance, it is they who have nodded and not Homer, for he has consistently presented the folk-tale in counterpoint to the epic narrative. The final scene between Nausicaa and Odysseus, therefore, is but another example of Odysseus' discreet resolution of a difficult problem as well as an artistic triumph for Homer.

University of Texas at Austin

Nicolas $P$. Gross

\footnotetext{
${ }^{17}$ To a considerable extent, Nausicaa's charm resides in her eloquence, and feminine persuasion often presents a problem for Odysseus. He uses the same formula, for example, to summarize his reactions to his affairs with Calypso (7.258) and Circe (9.33): all', emon ou pote thumon eni stêthessin epeithen. So too the awareness of the force of persuasion is extremely important in the recognition scene with Penelope. See A. Amory, "The Reunion of Odysseus and Penelope," in C. H. Taylor, Jr. (ed.) Essays on the Odyssey (Bloomington 1966) especially 120-121. Note that Penelope, to state that she is convinced of Odysseus' identity, says peitheis (23.230).
}

MOVING? TO BE SURE that you receive your copies of $C W$ on time, please let us know your new address as early as possible before you move. Send address-change to The Classical World, 325 Smith Hall, University of Delaware, Newark, DE 19711. 